\title{
大都市地域の生成・発展とそのゆくえ 東京圏を事例として
}

\section{Development and Future of the Metropolitan Area}

\author{
The Case of Tokyo
}

\author{
玉野和志 \\ Kazushi TAMANO
}

Urban Sociology has explored the social life of the people in the city. This paper examines the making of Tokyo metropolitan area and the women's activities in the suburbs. Firstly, it shows that migration from the country has made Tokyo metropolitan area since the 1950s and many people who migrated from the 1950s to the 1960s had been born before and after the Second World War. Secondly, it is shown that the populations move from the central Tokyo to the periphery has occurred and the prewar generation and the postwar generation has begun to live in the suburbs. The women's movement and activities has been developed on the suburban communities. Lastly, we argue that the migrations of these particular generations make these particular local communities in the metropolitan area. Through the making of a local community as such, Capitalistic industrial structure has an effect on the social life of the people in the city.

\section{1. 課題}

シンポジウムで筆者に与えられた課題は, 世代と移動という観点から, りわけ大都市 地域の変遷を, 可能ならば地方との関連も含めて, 明らかにしてほしいというものであ つた。なぜ世代と移動なのかといえば，少子高龄化や人口減少，限界集落などが大きな問 題になっているからだということだったのかもしれない.しかし，ここでは都市のローカ ル・コミュニティにおける人々の社会的世界を対象とする都市社会学研究にとって, 世代 と移動という問題は，実はもつとも重要な媒介変数であることを示してみたい.それはワ 一スが考えたような独立変数では決してないが，真の独立変数を従属変数へとつなぐ，も つとも重要な媒介変数なのである.ここでいう「真の独立変数」とは，マルクス主義の都 市研究や新都市社会学が主張した資本主義の世界システムにもとづく政治経済学的な要因 である。したがって，世代と移動という媒介変数を設定することで，都市をめぐる政治経 済学的な要因とコミュニティにおける社会生活とが，どのように結びつけて分析できるよ うになるかが示されることになる。 
なお，ここでの議論はその多くを筆者を中心とした共同研究の成果に負うている 野・浅川，2009]. 本来ならば，別途より一般的なデータによって補強すべき諸点につい ても，本稿ではそこでのデータをそのまま利用するにとどめている.その意味できわめて 不十分なデータにもとづく議論であることをあらかじめ断っておきたい.

本稿の構成は，以下の通りである.まずは，東京大都市圏の形成過程を，世代と移動と いう観点から，地方との関係で明らかにする. 次に，東京大都市圈内部の変遷と形成過程 に目を向ける.そこでは都市社会学をはじめとした日本の地域研究の変遷が，特定の世代 とその移動の過程にそって展開してきたことが示されるだろう.そのような点をよく示す ものとして，われわれの共同研究の対象となった東京圈の 2 つ郊外住宅地の事例が紹介 される.そこから，東京圈そのものの成立と東京圈内部の構成が，都市化や郊外化とよば れる都市の空間構造の変容として特定の地域社会を形成し，そのことを通して人々のコミ ユニティでの生活を規定していったことが明らかにされる.そこにはそれぞれのリズムと 周期にもとづく「都市の時間」と「コミュニティの時間」の交錯が見られるのである.こ のように，都市の空間構造の変容にうながされた特定の世代の移動にともなうコミュニテ イの社会的な形成過程を媒介として, 資本主義の下にある産業構造が人々の生活を規定し ていくのである。このような意味で，世代と移動は媒介変数として位置づけられる.論文の 最後では，このような観点から，地方との対比で大都市地域の果たすべき役割と都市研究 の課題について考えてみたい.

\section{2. 東京圏の形成過程}

それでは，まず東京圈そのものの形成を，世代と移動という観点から考えてみよう.図 1 に示したのは，東京都の人口の推移を区部と市町村部に分けて示したものである. 区部 は東京圏の中心部，市町村部が周辺部に対応すると考えるならば，この図は東京圏の中心 部と郊外との人口動態を示していると読むことができる. 戦後 1950 年代から 70 年ぐらい までは区部の人口が急激に増加する。それが70年代以降は徐々に減少していくが，東京都 全体としては漸増が続いているので，70年代以降は市町村部の人口が増加しているとい うことになる.95年以降はいわゆる都心回帰で，再び区部の人口が増えていくが，この点 についてはここではふれないことにする。

つまり，1970年までの高度成長期には東京の中心部の人口が増加し，その後都心部の 人口は徐々に減りはじめるが，周辺部の人口はそのまま増加していく。これを世代と移動 という点から解釈すれば，高度成長期に地方から東京の都心部へ就職や進学などで流入し た若い世代が，やがて結婚して新しい世帯を形成する際に，郊外へと移動していったと考 えられる. 50年代から 60 年代にかけて流入し，70年代以降郊外へと移動して世帯を形成 した中心的な世代を想定するとすれば，60年前後に進学および就職の時期を迎え，70年 


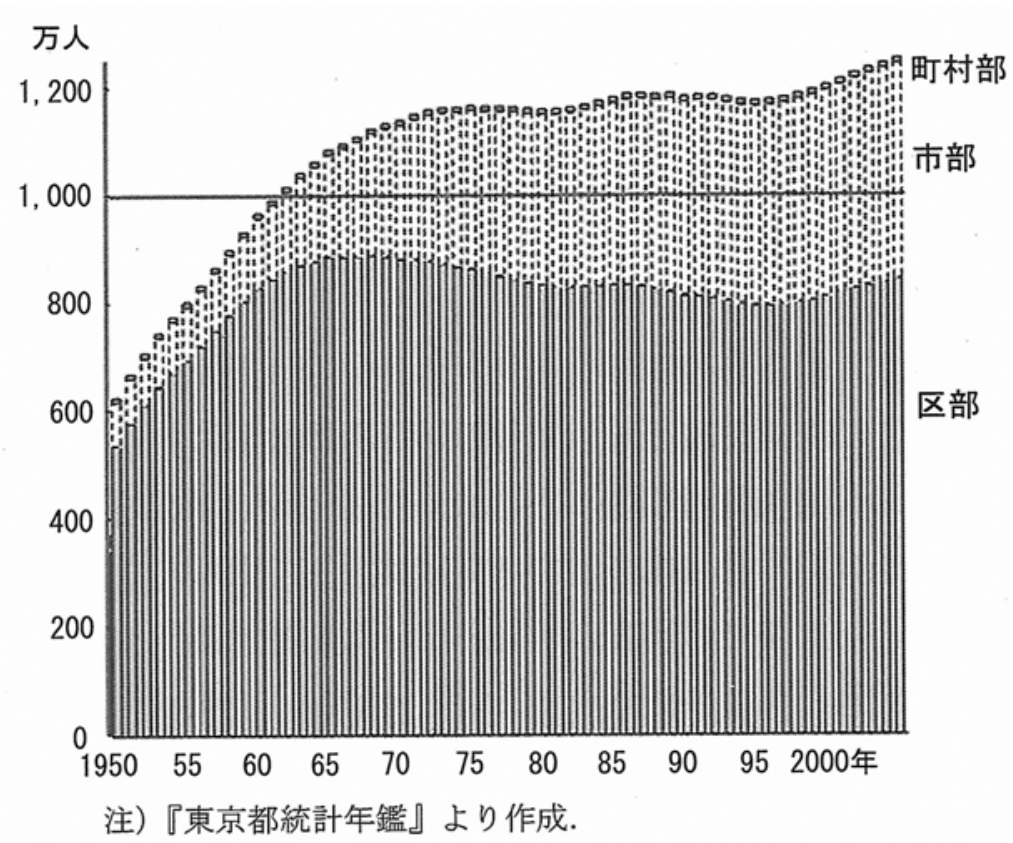

図1 東京都の区市町村部別人口推移

代以降に結婚, 子育ての時期を迎える1940年前後に生まれた人々が中心と考えることが できる、いわゆる戦後の団塊の世代よりも少し年長の, 戦前世代の最後ともいえる出生コ ーホートである。

このような想定は, 図 2 に示したデータによって, 少なくとも部分的には裏づけられ る。これはわれわれが東京周辺の郊外地域の一部で行った調査の結果にもとづくものであ る [玉野・浅川, 2009].2004年に30歳以上の女性を対象に行った調査で, 本人とその 配偶者の義務教育修了, 就職, 結婚の 3 つの時点での居住地を年代ごとに示したものであ る.戦前世代に当たる 60 歳以上の人には地方出身者が多く，特に配偶者である男性の場合， 就職でいったん東京都心部に流入した後で, 結婚して現在の郊外へと移り住んだ場合が多 いと考えられる.他方, 40 歳未満の年代では, 地方出身者と東京出身者がほぼ半々になっ ているが，地方出身者の場合，やはりいったん都心に流入してから郊外へ移動するという パタン自体は残っているようである. 若干特徵を異にしているのが，団塊の世代に当たる 50 歳代の人々で, この年代は東京都心部の出身者が比較的多く, かつ就職時にも都心に 居住していた経験を持つ人が多い.この点は調査対象地の特質にもよるので, 一般化はで きないように思うが，後で述べる戦前世代と団塊の世代の違いを考えるうえで興味深い.

さて，これらの点から大都市地域である東京圈とそれ以外の地方との関連について，い くつかのことを確認しておきたい.まず, 戦後の高度成長期における東京圈への地方から の人口流入は，1940年前後に生まれた戦前世代を中心とするもので, 結果としてこの世 


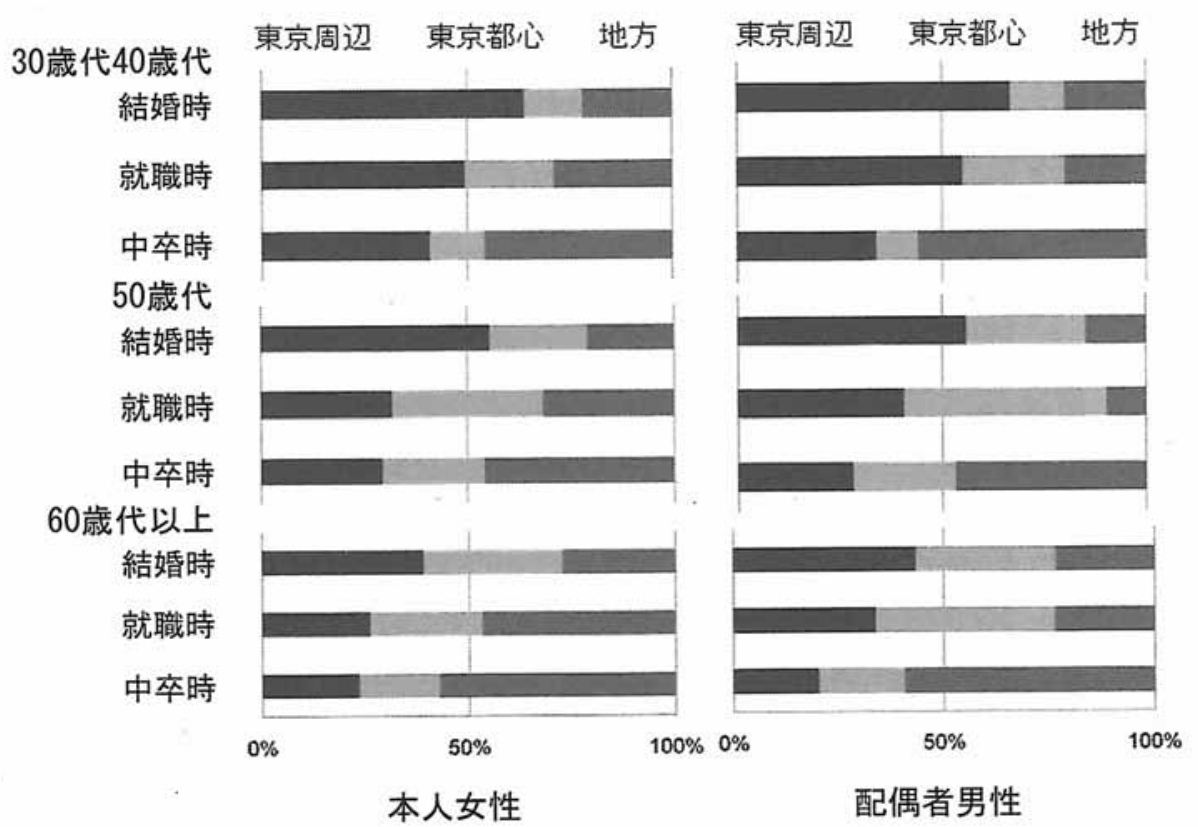

注）菅生・あざみ野地区の調査より作成.

\section{図2 年齢別・時期別の居住地域}

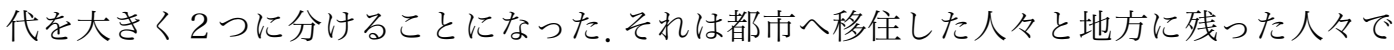
ある.そして，その後の世代からは徐々に都市出身者が増えていくので，戦後生まれの団 塊の世代においては都市定着者が優勢となっていく.その結果，団塊の子ども世代以降に なると，都市生まれの都市育ちが多く地元志向が強くなっていく.この点は昨今の若者の 地元志向としてょく言及されることではあるが，それはあくまで地方でも都市レべルまで の話であって，その他の地域ではこの年代の若者そのものが存在しないこともある点に注 意しなければならない.いずれにせよ，東京圏をはじめとした大都市地域の形成は，全国 レベルで見た場合，このような世代の不均等な分布を生み出したということを，ここでは 確認しておきたい.

\section{3. 東京圏内部の変遷}

次に, 東京大都市圈内部における変遷を, やはり世代と移動という観点から検討してみ たい.ここでもやはり 1940 年前後生まれの戦前世代と戦後の団塊の世代が中心になって いる.なぜなら，この年代が人口構成的にも非常に大きな比重を占めてきたからである.

戦後の復興期を終え, 高度経済成長が本格化する50年代から 60 年代にかけて，地方か ら移動した人口は，まず都心部に定着する.集団就職というかたちであれ，大学進学とい 
うかたちであれ，1940年前後に生まれた世代を中心として，まだ家族を構成しない若年 者が都心へと流れ込んだ.この時期の産業と人口の都市中心部への集中は，やがてさまざ まな問題をもたらすことになる.急激な人口増にともなうゴミ処理の問題や産業の集中に ともなう交通機関の整備を目的に建設されていった環七や環八などの幹線道路は, 騒音や 大気污染などの公害問題をもたらすことになる.学生運動と住民運動の高揚をへて, 美濃 部革新都政が成立する 60 年代後半から 70 年代にかけて, 団塊の世代は 20 代後半, 戦前 世代は30代前半を迎えていたことになる。

その後, 1970年を境に, 東京 23 区の人口は停滞ないし漸減するようになる。いったん 都心部へ流入した人口が，郊外へと移動しはじめたのである.このような人口の移動は, いうまでもなく政策的にも誘導されたもので, 都心における産業と人口の過密を緩和する ために, 工場の新規建設や拡張が制限され, 地方への分散が図られただけでなく, 多摩二 ュータウンを中心とした郊外住宅地建設が積極的に図られていった.それはちょうど戦前 世代と団塊の世代が結婚して新たな世帯を形成し，子育てをはじめる時期に当たっていた。 結婚したら親と同居するのではなく, 新しく核家族を形成し, 子育ては環境のよい郊外で という生活様式が賞揚されていった。そしてそのような近代的な家族が単位となって郊外 には市民的な共同にもとづく新しいコミュニティが形成されていくというのが，この時期 の市民意識論の内容であった.まさに 70 年代から 80 年代にかけての住民運動と市民運動

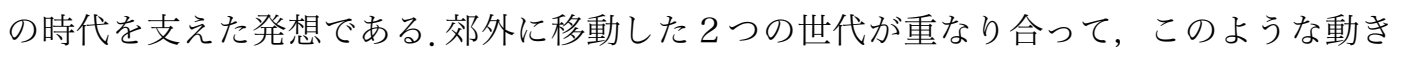
を担っていくことになる.

そして，80年代以降にはこのように形成されていった郊外住宅地を舞台に，子育てを 中心とした女性の地域での活動が花開いていく. 子育てをめぐる地域の教育や文化, 安全 な食品, 環境問題などへの取り組みが新たな市民活動として展開していく.地域文庫・親 子文庫の活動や子ども劇場・親子劇場運動, さらには生協による共同購入から生活クラブ 生協などによる代理人運動や生活者ネットなどの運動も展開していく.これらもみな団塊 の世代を中心とした, 郊外へと移動し, 定着していった世代が中心的な担い手になったわ けである。

さらに，90年代以降の時期になると，子育てに代わって高齢者の介護が大きな問題と なり, NPOやボランティア活動への期待が高まっていく.女性の地域での活動も子育てか ら介護へと移行していくだけでなく, ワーカーズ・コレクティブなどに示唆されるように, 仕事や職場への進出も強く意識されたものになっていく.このような市民活動のさらなる 展開には, 特定非営利活動促進法（いわゆるNPO法）の制定や介護保険制度の導入，男 女機会均等法の制定なども影響しているのであろう.

このように見てくると, 戦後の都市社会学を初めとした地域研究において, その時々に 話題となってきた研究課題は，いずれも戦前世代と団塊の世代の都心から郊外への移動, 郊外における近代家族の形成と子育て, 女性の就労, 介護というその時々の生活課題の変 
遷にちょうど対応してきたといっても過言ではないだろう.

次に，わ秃れが代表的な東京の郊外である多摩田園都市地域において確認することの できた事例［玉野・浅川，2009］を紹介することで，このような想定を具体的に裏づけ てみたいと思う。

\section{3-1 菅生地区における女性の市民活動}

われわれの共同研究の対象地のひとつになった菅生地区は，図３に示したように，東京 大都市圈の南西部に所在する郊外住宅地である.川崎市宮前区に位置し，多摩田園都市線 の宮前平駅からバスで 10 分ほど行ったところにある.小田急線と田園都市線のちょうど間 に位置しているので，交通の便はけっしてょいとはいえないが，郊外住宅地としての開発 は早く, 60 年代の後半から一戸建て住宅地の分譲が行われた. 当初分譲を行った開発業者 は東芝や富士通などの川崎市に事業所をもつ大企業や川崎市からの後ろ盾もあるというこ とで，その点を信頼して多くの住民が入居したのだという．ところが，一通り分譲が終わ ったところで，この業者が倒産してしまい，分譲地内の道路は舗装されることなく放置さ れることになった.調べてみると，地元の地主との間の権利関係も整理されておらず，や むをえず住民自らが自治会を結成し，長期にわたって権利関係を整理し，自分たちの負担 で団地内の道路を整備していったのだという.このとき，自治会の中心になったのは女性 たちであった.男性の方は当該企業に雇われていることもあって文句が言いづらく，自ず

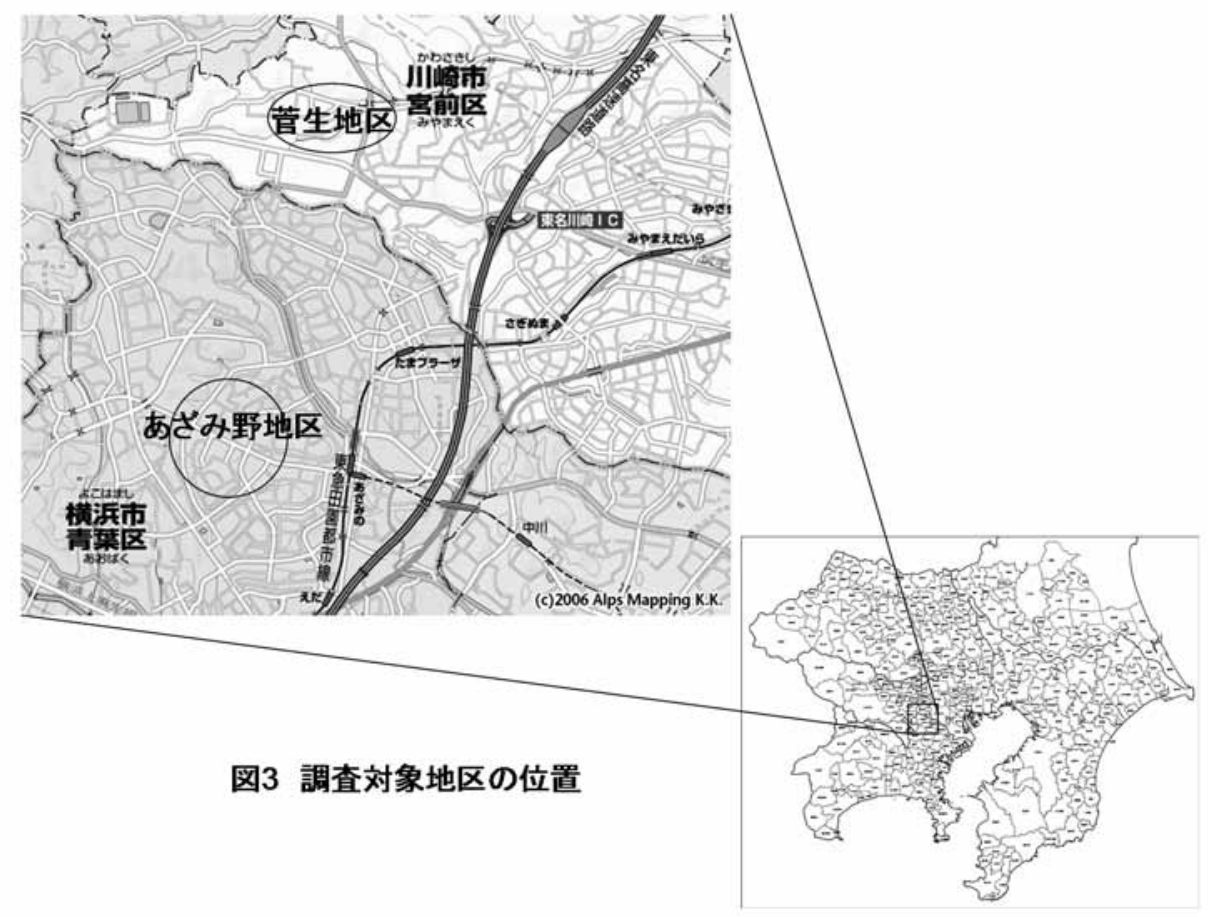


と女性が前面に出ることになったのだという.

同じ時期に，すぐ近隣を通る幹線道路沿いに流通センターの建設計画があることが知ら される。これがや゙て伊藤三郎川崎革新市政を誕生させることになる，有名な「流通セン ター建設反対運動」のはじまりである [長尾・加藤，1987．やがて「緑の憲法」制定へ と発展していくこの運動の中心を担ったのが, 菅生地区の団地自治会でも活躍していた女 性なのである.彼女とともに運動を担ったある女性は，もともと東京23区内に住んでいた が，近くに環七が通ることになって環境が悪くなり，ここは不便だが緑が多いということ で引っ越してきた.だから，その緑が削られ，交通量が増えてしまう流通センターの建設 には反対したが，地元の人にはよく身勝手だといわれたそうである.

他方，この地区にはもうひとり市民活動で有名な女性が住んでいる.こども文化センタ 一建設運動を担った女性である.郊外に移り住んだ女性たちにとって，大きな課題となっ たのは，子育ての拠点となる施設の確保であった。こども文化センターの建設運動につい ては, すでによく知られているので [長尾・加藤, 1987], ここではその近隣の地域に展 開した女性たちの学習活動について紹介しておこう [玉野編, 2003]. やはり郊外に移り 住んだこの地域の女性たちは，子育てをめぐるPTAでのつきあいをきっかけに，その後 も活動を続け, 広く地域の課題を考えるための学習活動を展開するようになる.そのため に，川崎市を通じて新生活運動協会から支援を受けることのできた生活学校を拠点として， さまざまな学習活動に取り組んでいく.やがて活動の拠点を求めて市民館分館の建設運動 を展開し，これを実現していく.さらに80年代以降は女性の自立を課題とした学習活動へ と進んでいき，これがやがて配食サービスと介護ヘルパー事業を中心とした有限会社設立 へと結実する.つまり, 介護と配食サービスを事業として展開する地域福祉サービス団体 を生み出していったのである.

以上のような菅生地区での女性を中心とした活動の展開は, 東京大都市圏の形成過程に おける地方から都心部への人口の流入と郊外への移動, 郊外での生活環境の確保, さらに は子育てから就労および高齢者の介護へという，家族周期段階にもとづき女性に課せられ ていった生活課題の変遷をよく示すものになっている.

次に，菅生よりはもう少し後に開発されたあざみ野地区の事例に進むことにしょう。

\section{3-2 あざみ野地区における女性の市民活動}

われわれの共同研究のもうひとつの対象地となったあざみ野地区は, 田園都市線あざ み野駅の西方に広がる, 菅生同様一戸建ての分譲団地を中心とした郊外住宅地である. 横 浜市青葉区に位置している.田園都市線にあざみ野駅が設置されたのは1977年のことで, その後 1993 年に横浜市営地下鉄が新横浜から接続したために, 現在では非常に乗降客の 多い駅になっている.これにともない周辺の住宅地としての開発は, 70 年代後半から 80 年代にかけて展開した, 比較的新しい郊外住宅地である. 
菅生よりも開発が 10 年ほど後であったために，ここでは戦前世代というょりも，戦後 の団塊の世代が最初に移動してきた世代であったと考えられる.移動・定着した時期も， すでに 80 年代に入っていたので， 70 年代の住民運動や子育てをめぐる市民活動の時代と いうょりも，生活クラブ生協などを中心とした生活者ネットの運動から，やがて高齢者介 護に関するボランティア活動などが展開していく時期に当たっている.ややり PTAなどで の活動をきっかけに多様な市民活動が展開していったようだが，この地域は他方でもとも との地主である地元層が，代々自治会の役員を独占するようなところもあったので，新し く流入した女性たちは，自治会の中で広報の仕事を請け負って自治会のニュースを発行す るなど，自分たちの存在を自治会に認めさせるために腐心した時期もあったという.すで に少子高齢化の時代に入っていたので，子育ての活動よりも老親介護に関する活動が現在 では中心になっている.他方で，結婚前には東京の都心部でばりばり働いていたような人 も多いので，子育てが一段落したところで再び働き始めたり，親の介護などもあってそう もいかないならば，自宅近くでできる仕事をということで，起業を検討している人もいる という [玉野編, 2003, 玉野・浅川, 2009].

さらに，近隣のたまプラーザなどでは，多摩田園都市としてのイメージを大事にしたミ ニコミ誌発行の活動なども行われている.川崎市と同様に, 横浜市でも国際交流に関する 市民活動がさかんで，青葉国際交流ラウンジなどでの日本語学級などのボランティアに参 加している人も少なくない.川崎市も含めたこの地域に国際交流ボランティアに参加する 女性が多いことの背景には，次のような事情もある [福田，2009].川崎市の宮前平には 主要な大企業の社宅が集積していて，ここには海外赴任から帰った家族が多く住しでいた ために, 近隣の小学校が文科省の帰国子女教育のモデル校に指定されていたりしていた. 海外赴任から帰った家族はいったんこの社宅に居住した後, 近辺の郊外住宅地へと転出し ていったのだという。そのため，あざみ野地区にもこのような海外生活を経験した女性が 多く, 横浜市が難民の受け入れ支援を行っていることなどとも関連して, 国際交流のボラ ンティアに参加しょうとする女性に，それなりの厚みが生まれているというわけである。

以上のように，あざみ野地区の場合，菅生地区とはまた少し違った，戦後世代の比較的 若い年代の女性がへてきた都心での就労経験や海外での生活経験を反映した独自の市民活 動が展開していることがうかがわれる。ここでも彼女たちの世代と移動にもとづくコミュ ニティの構成のされ方が，そこでの市民活動のあり方を規定していることがわかる.

\section{4. 世代と移動によるコミュニティの社会的形成}

世代と移動という観点から，東京大都市圈そのものの成立過程と，その後の東京大都市 圈内部に抢ける都心と郊外の形成過程について見てきた。その結果，1960年代以降，日本 の都市社会学がテーマとしてきた一連の議論が, 単なる一般的な社会現象として理解され 
るべきものではなく, 特定の世代の, 特定の時期における, 特定の場所への移動の結果生 じた，特定のコミュニティにおける現象として理解すべきことが明らかになったように思 う. その時代その時代において注目すべき社会現象は, つねに特定の世代と移動の結果生 じた特定のコミュニティにおける社会現象として，実際には生じている。したがって，そ の時代を代表するような地域もあれば，一昔前の課題が今まさに問題になっている地域も ある、われわれが具体的なコミュニティの課題を探究しょうとするならば，つねにそのよ うな意味での各地域の位置づけを確認しておく必要がある。そのような理解を深めるうえ で，対象となる地域が，具体的にどのような世代の，いかなる移動の結果，生じてきたも のであるかを知ることが重要なのである.

とりわけ, 都市のローカル・コミュニテイは長くその地域で暮らしてきた人々だけで構 成されているわけではない，さまざまな世代の人々が，それぞれの時期に，いろいろなと ころから移動してきては定着し，それらの人々が相互に重なり合いながら集住している. ここではそのような特定地域の歴史的な構成を「コミュニティの社会的形成」と呼んで おくことにしょう.都市のコミュニティはつね齐にのような移動の時期を異にする一群の 人々が絡み合って存在し，ときとしてその一部が世代として集合的な意味をもつ場合があ る.その点についてはまた後でふれることにして，ここではまずそのような意味でのコミ ユニティの社会的形成が，媒介変数としての意味をもつ点について確認しておきたい.

シカゴ学派は, 人口の量と質が独立変数として都市的な生活様式を生み出すと考元 た [Park and Burgess, 1924; Wirth, 1938].しかし, マルクス主義の都市研究の立場か ら, それは資本主義にもとづく世界経済のもとでの特定地域の政治経済学的な位置づけに よって規定されるものであり, 独立変数ではなく従属変数であると主張された [Castells, 1977, Pickvance, 1977]. その後の都市社会学研究は, そのような立場を基本的に受け入 れながらも, 都市という変数がごく限られた範囲ではあるものの, 独立変数としての意味 をもつ側面を探求してきたといえる [Fisher, 1976, 奥田・広田, 1983]. しかし重要な のは，政治経済学的な要因が単純に都市住民の社会的世界を規定するのではなく，その間 にいくつもの媒介変数が介在するという点を明らかにすることである.世代と移動という 問題は，実はそのような意味をもつ変数であり，資本主義の世界経済は特定地域の社会的 な形成過程を通して，具体的なコミュニティのあり方を規定している。そのことを明らか にすることが重要なのである.

東京大都市圈に関するここでの事例を題材に，この点について敷衍しょう.われわれの 共同研究が対象とした東京の郊外住宅地は, 50 年代から 60 年代にかけて, 地方から東京 都心部へといったん流入した人口が，60年代から 70 年代にかけて，郊外へと移動するこ とで社会的に形成されたものである。このうな大きな意味での人口移動は，いうまでも なく高度成長期に抢ける産業政策と労㗢力需要によって引き起こされたものである.つま り資本主義世界経済の下での日本経済の高度成長政策は，直接に人々の生活を決定づける 
のではなく，産業発展の先端地区としての東京圈の空間的な位置づけとそれを支える労働 力の受け㿼としての住宅地形成という，都市全体の空間的な構造をまずは規定していった と考光られる。空間的な編成に応じて，人々が地方から都心へ，さらには郊外へと移 動し，定着していくことを通じて，人々の生活が大きく枠づけられていったのである.ま さに資本主義経済による都市の空間構造の決定によって，個々のローカル・コミュニティ が社会的に形成されていくというメカニズムである.

このようなマクロなレベルでの，グローバルな世界システム，国家，都市のレベルでの 空間構造を前提に，人々が移動・定着し，コミュニティが社会的に形成されていく.その 歴史的な流れは，まさに通常いうところの社会の歷史的変遷であり，時代の変遷を意味し ている。とりわけ都市の成長・発展の過程で，特定の地域の空間利用のあり方がこのよう に時代をへて変化していく側面を，ここでは「都市の時間」と呼んで㧈こう.都市の特定 のコミュニティは，マクロに見るならば，そのような都市の時間に応じて，たとえば漁村 から農村, 農村から工業地带, さらには住宅地へと変遷していく.しかしながら, このよ うな歴史の流れに翻弄されながらも，特定のコミュニティに移動・定着した人々には，そ れぞれのライフコースの段階に応じて，就労や結婚，子育てや介護というそれぞれの時間 が刻まれていく、これをここでは「コミュニティの時間」と呼んでおこう.特定のコミュニ ティはそこに暮らす人々のライフコースの諸段階に応じて，その時々の生活課題の解決を 迫られ，人々の集合的な営みを生み出していく，それは多くの場合，個々の家族を単位と した家族周期段階の集合的な効果として，独特のリズムと時間を刻んでいく.この「コミ ユニティの時間」と「都市の時間」の絡み合いの中から，特定の世代が集合的な意味を帯 びる場合がある。

ここでの事例でいうならば，就労や進学にともなう地方から都心への移動，さらには結 婚や子育てにともなう郊外への移動という，この時代の「都市の時間」にちょうど対応す るかたちで家族周期段階を刻んだ世代として，1940年前後の出生コーホートと1950年前 後の出生コーホートを考えることができる，とりあえず前者を「戦前世代」，後者を団塊の 世代を中心とした「戦後世代」と呼んで抢こう.両者の区別は流動的で明確に区分できる わけではないが, 後述の知見から, 戦前と戦後のどちらにより強く社会化されているかが

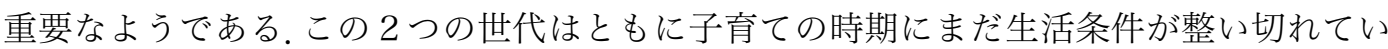
ない郊外へと移動し，まずは子育ての環境整備に，次いで食の安全や緑を確保する必要に 迫られた. 東京の郊外住宅地が整備されはじめた 60 年代から 70 年代にかけて，子育てを めぐる女性の地域での教育文化運動がさかんに展開したのは［増山，1986，このような 背景による.これは菅生地区の事例に典型的に示されている通りである. その後, 子育てか

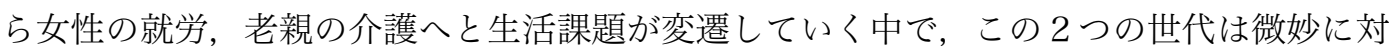
応を異にしていく. 戦前世代があくまで女性の家庭役割の範囲内での就労と自立をめざし たのにたいして，戦後世代は女性の就労と自立そのものにより傾斜した対応を模索するよ 


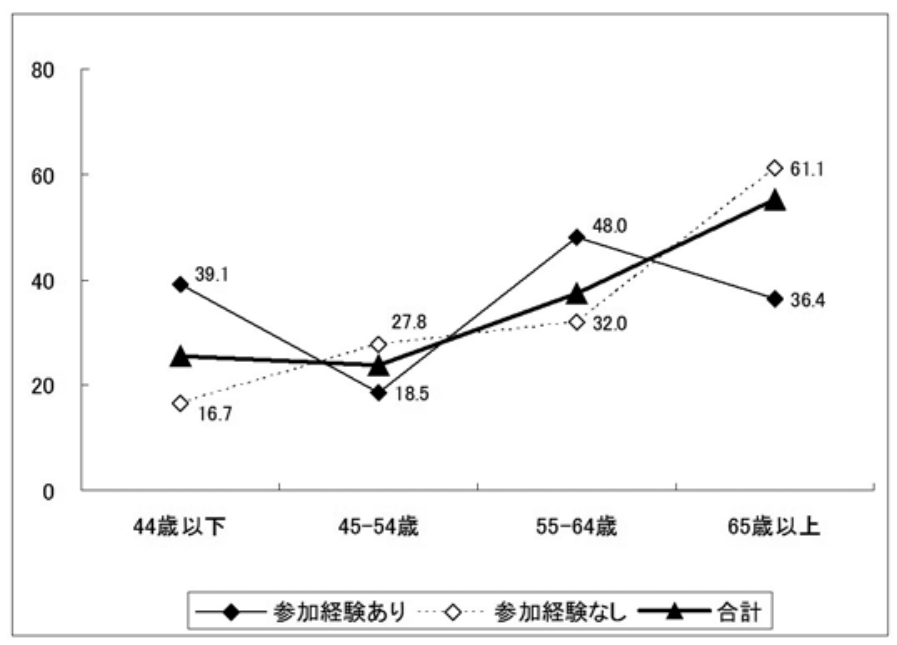

注）[高木, 2009］の分析結果より作成. 縦軸は肯定する人の比率を表示.

\section{図4 子ども集団参加経験による年齢別性別役割意識の違い}

うになる. 戦後世代が戦前世代よりも地方出身者より都市出身者が多いことや, 菅生地区 に比べた場合のあざみ野地区の市民活動の特徴の中に，そのような傾向が読み取れる.

このような世代的な違いを端的に示すデータとして, 図 4 を示しておこう. 性別役割分 業の意識を肯定する意見は，戦後生まれよりも戦前生まれの方が高い傾向がある.そして， この傾向はかつて子育てに関する活動に参加しなかった人々の中では特に変化はないが, 参加した人々の中では, 戦前生まれにおいて性別役割分業を肯定する意見が多いのにたい して，戦後生まれでは否定する傾向が強い.このことが戦前世代においては子育てが終わ った後も, 主婦として地域を基盤とした活動が模索され, 継続されるのにたいして, 戦後 世代はそれにこだわらず，より広域の活動や就労への傾斜を示すという違いをもたらして いると考えられる.このことがさまざまな市民活動の領域で, 活動の継続を困難にしてい る共通の背景をなしていることに，少し具体的な市民活動に関わったことのある人ならば, すぐに思い当たることだろう［佐藤編，1988，西城戸・角，2006，2007］.

要するに，都市の時間とコミュニティの時間との絡み合い，つまり移動と定着の夕イミ ングとその時代その時代の意識やイデオロギーのあり方によって, 特定の出生コーホート がコミュニティにおいて世代として集合的に成立する場合がある.それが，ある意味では 特定のコミュニティや都市における独自の社会的世界を作り出すわけで, 都市社会学がこ れまで独立変数として扱おうとしてきた要因は, 実はコミュニティの社会的形成という媒 介変数を介して, 都市空間を構造的に枠づける真の独立変数としての政治経済学的要因の 規定力ゆえに，必然的に生じてくるものだったのである [Gans, 1962]. 構造にたいする 人間の主体的な対応とか,「生活の論理」などという曖昧な言い方をする必要もなく, 構 造的要因によるコミュニティの社会的な形成過程における，都市とコミュニティの時間の 
相克から，集合的に生じるのが，人々の主体的な営みであり，社会的な活動や運動なので ある。

世代と移動によるコミュニティの社会的形成を，媒介変数として都市とコミュニティの 間に位置づけることで，構造に規定されながらも主体的に生きようとする人間の姿を，都 市社会学はどのような視点から捉えることができるかが，明らかになったように思う。こ こでは詳しく述べないが，それは同時に都市社会学における社会地区分析とコミュニテ イ・スタディという方法の問題とも関連する [玉野・浅川, 2009].

\section{5.世代と移動から見えてくる都市社会学の課題}

最後に，シンポジウムでの他の報告やシンポジウム全体の課題との関連で，大都市地域 の研究が考元るべき課題について述べておきたい.

シンポジウム当日の山下報告や徳野報告は, 分権改革以降の地方のきわめて困難な状況 や，「限界集落」などと呼ばれる中山間地区のコミュニティとその周辺都市をどう考元る かという切迫した課題に答えようとするものであった，その意味では，東京大都市圈のか なり恵まれた郊外住宅地に焦点を当てた本報告は，いささかピントはずれのものであった． 本稿でふりかえった地域研究の課題とそれが典型的に現れる地域の現実という点でいえば, 今はまさに地方の周辺部を典型とした人口減少と地域再生という課題が旬であり, 大都市 地域はその課題が不明確な後裔と位置づけられるのかもしれない.それでもそこでの独自 の視点と課題を探ってみたい.

東京大都市圈形成の裏側としての地方の現実を考元た場合，世代と移動という観点から いうならば，年齢構成と世代そのものの不均等な分布という点を看過してはならない.す でにふれたように，地方にはすでに都市部では今後の定着と地元志向が期待される団塊ジ ュニア世代以降の人口が存在していない場合が多いのである.このような不均等が生じて いるということは，単なる経済的な問題ではなく，社会的な構成の単位としても，そのよ うな地方だけを単体として切り離して自立せよという意味での分権や自治の要求は非現実 的であることがわかる。にわかに道州制に同意するわけではないが，何らかの地域と地域， コミュニティと都市を結びつける仕組みを作ることは不可避であろう.問題は，その担い 手や単位がこれまでと同様に「国家」ないし「行政」であるべきなのか，それとは違った 新しい枠組を考えるべきなのかという点にある.

山下報告や徳野報告が強調していたように，もはや集落や自治体にこだわっていたので は，個々の家族の存続も扔ぼつかないのが現実であろう，そのような制度的体組にはこだ わらない，何らかの人と人との関係を支援する地方と都市，コミュニティとコミュニティ を結ぶ新しい仕組みを作らなければならないというのが，討論者の鯵坂氏も含めた当日の 議論の方向性であった。そこで私はあまり深い考えもなく、「都市リージョン」という言葉 
を使ってしまったのであるが，その意味するところを少し述べてみたい.

「都市リージョン」という言葉が適切であるかどうかは別にして，そこで言いたかった のは，さまざまな資源の集積する都市が，制度的総体としてではなく，個々のネットワー クとしてその外側との間に何らかの支援関係を形成していくというイメージである.拡大 家族としての行き来や援助であったり, サポーターというかたちで一時的な滞在者を地方 が迎え入れたり，観光や援農なども含んだグリーンツーリズムや，都市のNPOがさまざ まな地方の支援活動に取り組むようなことも考えられる.それら個別のネットワークを自 治体や国家が支援するということも考えられるだろう。そのような都市のさまざまな主体 によるリージョナルな社会的関係が広がっていくことを前提に, 特定の都市と特定の地方 との関係の総体を考えるならば, それは都市でも地方でもなく, 都市リージョンと呼ぶべ きものかもしれない.

さらに，より広い範囲では都市と都市との国境や民族を越えたつながりも，都市リージ ヨンと呼ぶべきものであろう。こちらは社会的な関係というよりも，金融や経済の動きを 含めたグローバルな生産活動が中心であり, その社会的な意味合いはかなり異なるが, 自 治体や国家を必ずしもその単位とはしないという点では, 都市リージョンと呼ぶべきもの である. 要するに, 経済的な発展モデルを考えるにせよ, 再配分としての支援関係を考え るにせよ, 従来までの国家や自治体を単位とした発想ではなく, 都市を基盤としたリージ ヨナルな関係を考えていく必要があるということである.もちろん, その結果, 国家や自 治体の果たす役割が少なくなるというわけでは決してない. 国家や自治体の役割も, その ような個々の関係への個別の支援を視野に収めるべきであるというだけのことである.

そして，そこでも世代と移動にもとづくコミュニティの形成に着目することで，そのよ うなつながりの実態が見えてくる.都市社会学は世代と移動にもとづくコミュニテイの社 会的形成の実態を明らかにすることを通して，グローバルな世界システムとコミュニティ の社会生活とを結びつける, 都市のリージョナルな存立形態を見いだすことができるので ある、そして, そのような学問的な営みにもとづいて, 実践的・政策的な貢献をも果たし ていくことが求められるのである.

文献リスト

Castells, M. 1977. La Question Urbaine. F.Maspero. 山田操訳,『都市問題』，恒星社厚生閣， 1984

Fischer, C.S. 1976. The Urban Experience，松本康・前田尚子訳，『都市的体験』，未来社，1996

福田友子，2009,「後続世代の女性たちと『地域の国際化』—菅生・あざみ野における外国人支援 活動参加者の社会的背景」, 玉野和志・浅川達人編『東京大都市圈の空間形成とコミュニテ イ』, 古今書院, 319-337

Gans, H.J. 1962. "Urbanism and Suburbanism as Ways of Life: A Re-Evaluation of Definitions" in Rose, A. M. ed., Human Behavior and Social Proceses. 625-48. Boston, Houghton-Mifflin. 
増山均, 1986, 『子ども組織の教育学』, 青木書店

長尾演雄・加藤芳朗, 1987, 「住民運動の展開と行政対応」, 島崎稔・安原茂編『重化学工業都市の 構造分析』, 東京大学出版会, 1987, 723-765

西城戸誠・角一典，2006，「転換期における生活クラブ生協運動の現状と課題——生活クラブ生協 北海道を事例として」, 『現代社会学研究』, 第 19巻, 21-40

西城戸誠・角一典, 2007, 「生活クラブ生協再考——生活クラブ生協の『衰退』をめぐる仮説群の 整理」『京都教育大学紀要』, No.107, 73-90

奥田道大・広田康生編訳, 1983, 『都市の理論のために』, 多賀出版

Park, R E. and Burgess, E W. 1924. Introduction to the Science of Sociology, New York, Greenwood Press.

Pickvance, C.G. 1977. Urban Sociology. 山田操・吉原直樹・鯵坂学訳, 『都市社会学一一新しい理論的 展望』，恒星社厚生閣，1982

佐藤慶幸編, 1988, 『女性たちの生活ネットワーク——生活クラブに集う人びと』, 文眞堂

高木竜輔, 2009, 「女性の政治意識と政治参加」, 玉野和志・浅川達人編『東京大都市圏の空間形成 とコミュニティ』，古今書院，355-367

玉野和志・浅川達人編，2009,『東京大都市圈の空間形成とコミュニティ』，古今書院

玉野和志編，2003，『市民活動団体調査報告書一一横浜市青葉区・川崎市宮前区周辺を事例として』， 東京都立大学都市研究所・共同研究 I 「大都市における環境と社会経済システムの再編に関 する総合的研究」

Wirth, L, 1938. "Urbanism as a Way of Life"., American Journal of Sociology, Vol.44, 3-24, 高橋勇悦訳 「生活様式としてのアーバニズム」, 鈴木広編 『都市化の社会学 [増補]』127-47, 誠信書房, 1978.

（たまの かずし／首都大学東京教授） 